\title{
Diverticulum of the buccal mucosa: a rare case report and review of the literature
}

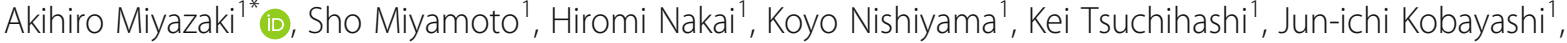 \\ Kazuhiro Ogi ${ }^{1}$, Hironari Dehari ${ }^{1}$, Tadashi Hasegawa ${ }^{2}$ and Hiroyoshi Hiratsuka ${ }^{1}$
}

\begin{abstract}
Background: Cases of diverticula of the buccal mucosa are extremely rare. Literature searches of databases such as PubMed/MEDLINE for this condition have revealed only 10 case reports. In this case report, we describe our experience in the management of this rare condition and review the previous 10 previously reported cases.

Case presentation: A 66-year-old man presented with a pouch containing inspissated food debris located posterior to the papilla of the parotid duct in his left buccal mucosa. The diagnosis of a diverticulum arising from the buccal mucosa was confirmed based on clinical and radiographic findings. Gross examination of the locally resected tissue specimen revealed a pouch measuring $14 \mathrm{~mm}$ in diameter and $8 \mathrm{~mm}$ in depth, that was whitish in color and had an elastic, soft, and smooth surface. Microscopic examination revealed a cyst-like lesion lined by stratified squamous epithelium and granulation tissue, with a chronic inflammatory infiltration in the peripheral stromal tissue of the epithelial layer. After surgical excision of the lesion, there was no recurrence during the follow-up period of 5 years and 10 months.

Conclusions: We have presented a rare case of a diverticulum of the buccal mucosa. This is the first report of a case confirmed not only by the clinicopathological findings, but also by computed tomography and magnetic resonance imaging findings. From the magnetic resonance imaging and intraoperative findings, we inferred that the diverticulum was caused by an idiopathic developmental anomaly due to a partial defect of the buccinator muscle.
\end{abstract}

Keywords: Diverticulum, Oral cavity, Buccinator muscle, Buccal mucosa, Buccal glands

\section{Background}

A diverticulum is a protrusion of the inner lining of the digestive tract through a defect in the outer muscular coat to form a small pouch with a narrow neck. The commonest site for development of diverticula is in the lower left portion of the colon. The presence of diverticula is often referred to as diverticulitis, presumably in reference to the irritation caused by retained fecal material [1].

Diverticula of the buccal mucosa are very uncommon. The first report of a diverticulum in the buccal mucosa was described by Bailey [2] as a case of a voluminous diverticulum arising from the buccal sulcus and extending into the neck. Since then, only nine cases have been reported in the literature [3-9].

We herein report a case of a diverticulum of the buccal mucosa, confirmed by clinical examination, computed

\footnotetext{
* Correspondence: amiyazak@sapmed.ac.jp

'Department of Oral Surgery, Sapporo Medical University School of Medicine, South-1, West-16, Chuo-ku, Sapporo 060-8543, Japan

Full list of author information is available at the end of the article
}

tomography $(\mathrm{CT})$, and magnetic resonance imaging (MRI), and discuss the etiology of this rare condition.

\section{Case presentation}

A 66-year-old Japanese man was referred to our university hospital in April 2011 with a complaint of food impaction in his left buccal region. The patient had no history of injury, tumor, or cyst in the oral and maxillofacial region. $\mathrm{He}$ had a medical history of hypertension, gastric ulcer, gout, nephrolith, and alcohol dependence, but no family history of congenital anomalies. He had been smoking 10-15 cigarettes per day for 45 years. He denied having any allergies. On general physical examination, his physical and nutritional statuses were good. Upon intraoral examination, an orifice containing inspissated food debris was observed posterior to the papilla of the parotid duct in the left buccal mucosa. Neither a mucinous discharge nor a communication with the parotid duct could be observed. A pouch measuring $14 \mathrm{~mm}$ in diameter and $8 \mathrm{~mm}$ in depth was noted after removing the food debris (Fig. 1). A CT

(c) The Author(s). 2018 Open Access This article is distributed under the terms of the Creative Commons Attribution 4.0 International License (http://creativecommons.org/licenses/by/4.0/), which permits unrestricted use, distribution, and reproduction in any medium, provided you give appropriate credit to the original author(s) and the source, provide a link to the Creative Commons license, and indicate if changes were made. The Creative Commons Public Domain Dedication waiver (http://creativecommons.org/publicdomain/zero/1.0/) applies to the data made available in this article, unless otherwise stated. 


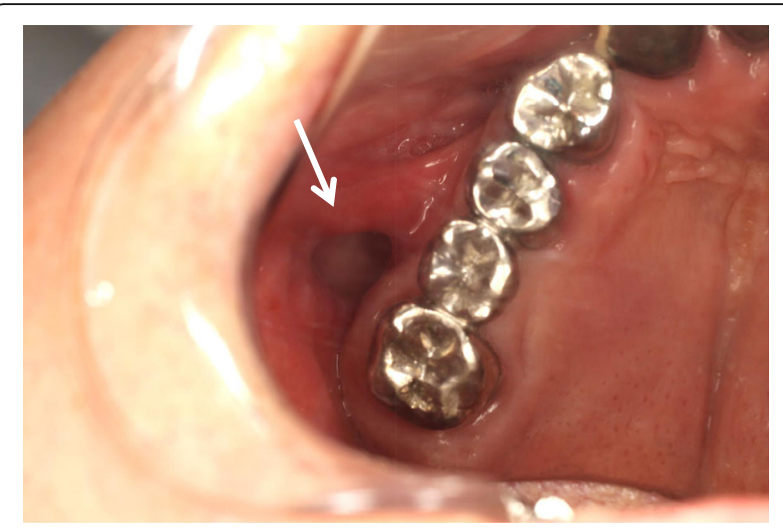

Fig. 1 Intraoral view of the buccal mucosa. A pouch in the left buccal mucosa is open, demonstrating a diverticulum (mirror image)

examination revealed a discontinuity of his buccal mucosa and a cavity containing fluid and air (Fig. 2a, b). An additional CT image with radiopaque, contrast medium-soaked gauze placed in the cavity outlined the extent of the pouch (Fig. 3a, b). The MR examinations provided T2-weighted images that showed a pouch with an opening and a slightly thickened wall, with a partial defect in the buccinator muscle on the left side (Fig. 4a, b). Gadolinium-enhanced T1-weighted MR images revealed enhancement of the wall extending over the surrounding tissues antero-posteriorly in the buccal lesion and superiorly in the maxilla on the left side, which was considered to indicate an inflammatory reaction (Fig. 4c, d). The lesion was diagnosed as a diverticulum of the buccal mucosa and was surgically resected with the patient under general anesthesia. A partial defect in the buccinator muscle was found underneath the pouch during the operation.

Macroscopically, the excised tissue specimen showed a pouch measuring $14 \mathrm{~mm}$ in diameter and $8 \mathrm{~mm}$ in depth, that was whitish in color and had an elastic, soft, and smooth surface. (Fig. 5). Microscopic examination revealed a cyst-like lesion lined by stratified squamous epithelium and granulation tissue, with chronic inflammatory cell infiltration in the stroma. The affected mucosa was focally depressed and the muscular tissue below the lesion could not be clearly visualized, though the muscle tissue was partially observed in the surrounding tissue (Fig. 6).

These findings led to the final diagnosis of a diverticulum of the buccal mucosa. There has been no subsequent food impaction and no evidence of disease recurrence in the 5 years and 10 months since the lesion was resected.

\section{Discussion and conclusions}

A diverticulum refers to the presence of an outpouching in the wall of the digestive tract mucosa, such as the colon or small intestine. The most common type of diverticulum affecting the colon is the pseudodiverticulum, in which the saclike mucosa herniates or projects through the muscularis propria [1]. There have been few reports of diverticular disease in the oral cavity. However, it is possible that some cases were not reported due to an incorrect diagnosis, asymptomatic clinical course, presence of few symptoms, or low morbidity of the lesion.

The patient characteristics from the 11 reported cases of buccal diverticula, including our case, are presented in Table 1. There was an obvious sex predilection, with nine patients being male and only two being female. The age range for all reported cases was 42-89 years (mean age, 68 years) and there was a predisposition for elderly individuals. Four cases had two pouches, bilateral or unilateral, and seven cases had one pouch. The reports of this lesion are predominant in Japan with eight patients, and the remaining 3 cases comprise one from Taiwan and two from the United Kingdom. Although nine cases

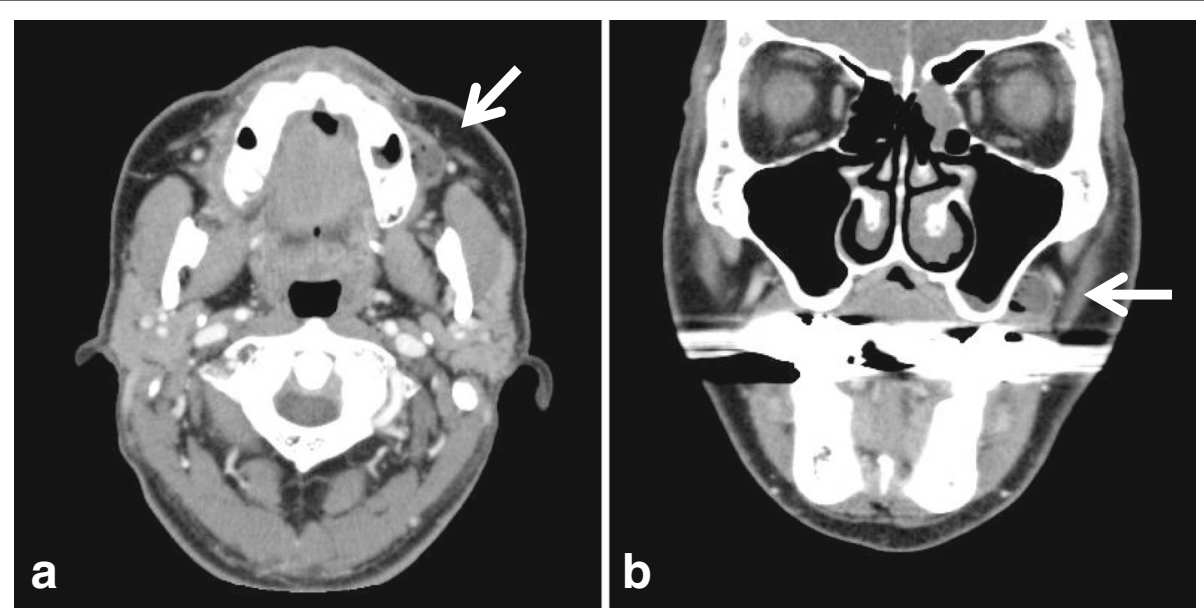

Fig. 2 Computed tomography images, a) axial view, b) coronal view, showing a deflection of the buccal mucosa and a cavity containing fluid and air (white arrow) 


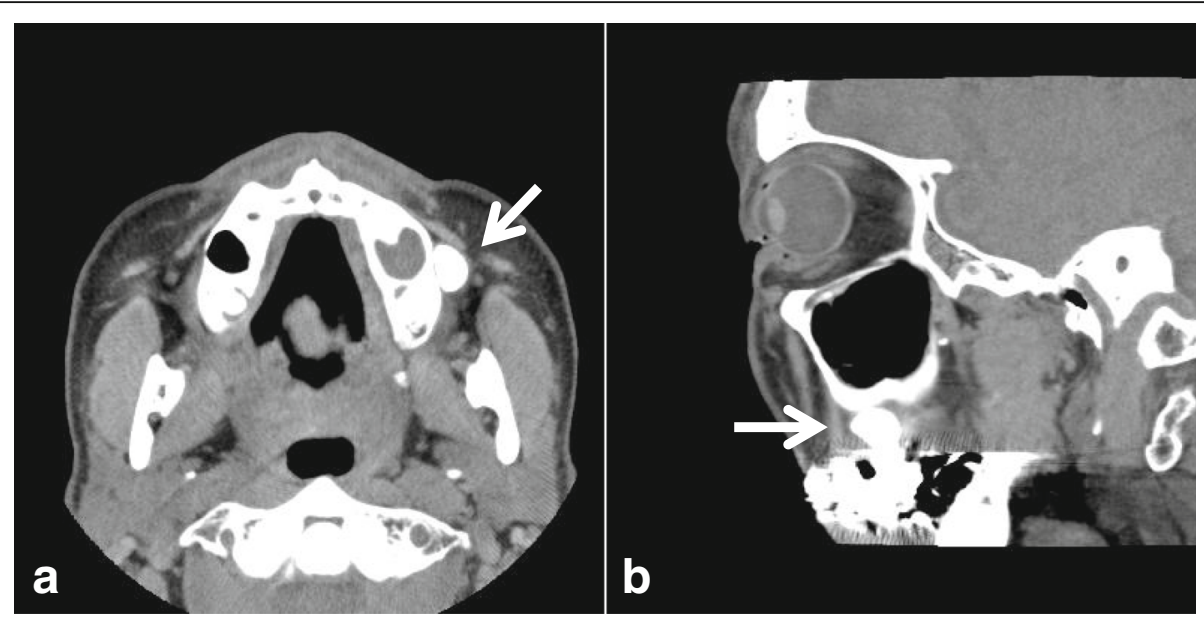

Fig. 3 Computed tomography images, a) axial view, b) coronal view, with radiopaque, contrast medium-soaked gauze placed in the cavity which outlines the extent of the pouch (white arrow)

actually belong to the East Asian nations, the influence of the ethnicity is unclear and further case presentations from other nations are expected to elucidate this aspect.

The etiology of the buccal diverticulum is unclear, though some theories have been reported. First, the cheek is anatomically composed principally of the buccinator muscle, which consists of three groups of muscle fibers [10]. It has been proposed that a diverticular lesion is caused by a developmental anomaly occurring due to partial dissection along those muscle fibers $[3,4]$.

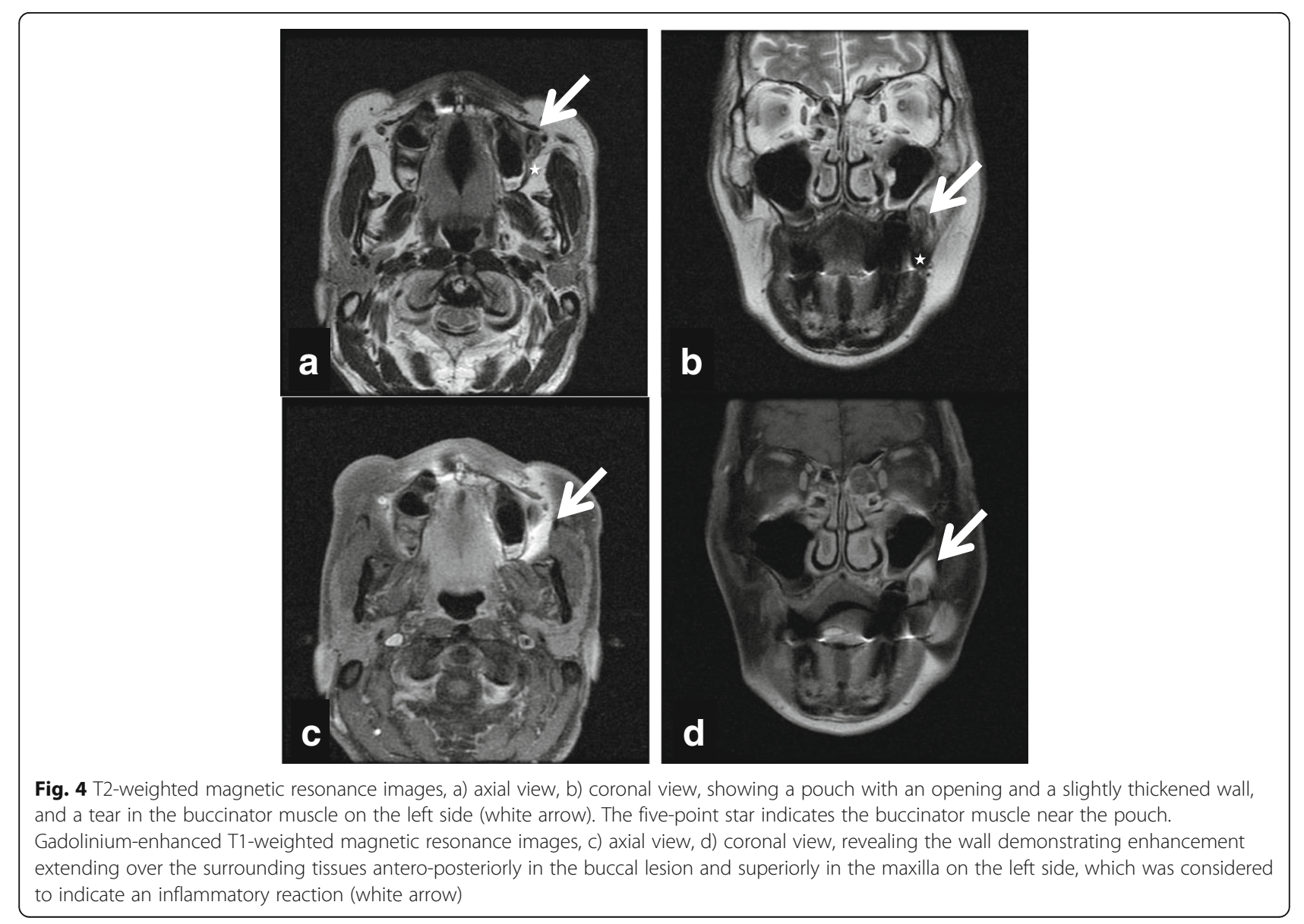




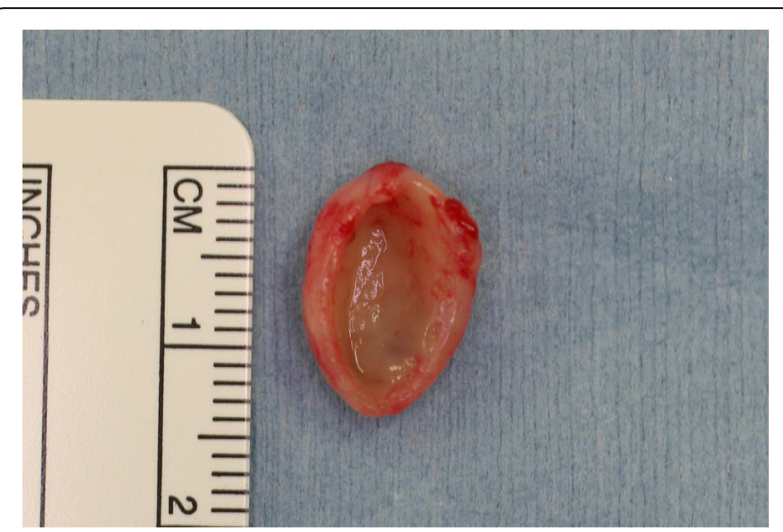

Fig. 5 Macroscopic findings. The macroscopic appearance of the excised tissue specimen shows a pouch measuring $14 \mathrm{~mm}$ in diameter and $8 \mathrm{~mm}$ in depth, that is whitish in color, with an elastic, soft, and smooth surface

Second, Rowson [5] postulated that chronic food inspissation causes a small traumatic lesion, which might progress into the formation of a diverticulum over time due to thin, atrophic mucosa and poor muscle tone. Kubo et al. [6] also suggested the possibility of a relationship with chronic food inspissation due to the disease's prevalence in the elderly, in whom poor oral hygiene is common. Third, Bailey [2] postulated that diverticulum formation may result from abnormal salivary tissue growth. Hypothetically, a salivary gland neoplasm arising from aberrant salivary tissue may become necrotic, and subsequently form a diverticulum in the normal squamous buccal mucosa. Fourth, it has been suggested that diverticula of the buccal mucosa may be due to idiopathic developmental defects resulting from invagination of the primary epithelial band, or may represent aborted development of accessory parotid primordial invaginations [7] or that of buccal glands [9]. The etiology remains unclear because sufficient evidence supporting any of these theories has not been collected. In our case, the diverticulum appeared to be an idiopathic developmental anomaly. Furthermore, a partial defect in the buccinator muscle fibers was observed on microscopic examination. The above stated evidence suggests that the type of diverticulum affecting the buccal mucosa was a pseudodiverticulum resulting from a defect in the buccinator muscle. In our case, dermal or epidermal inclusion cyst and fistulous tract could be excluded from the differential diagnosis since the morphology was that of a pouch but not a cystic or ductal structure. Furthermore, because of lack of keratinizing stratified squamous epithelium lining and keratin in the lumen or remarkable inflammatory granulation tissue and abscess, the diagnosis was supported from the histopathological aspect.

With respect to clinical manifestation, the diverticula appeared as asymptomatic lesions in five of the reported cases, while the other cases presented with halitosis, food impaction, or swelling. Surgical

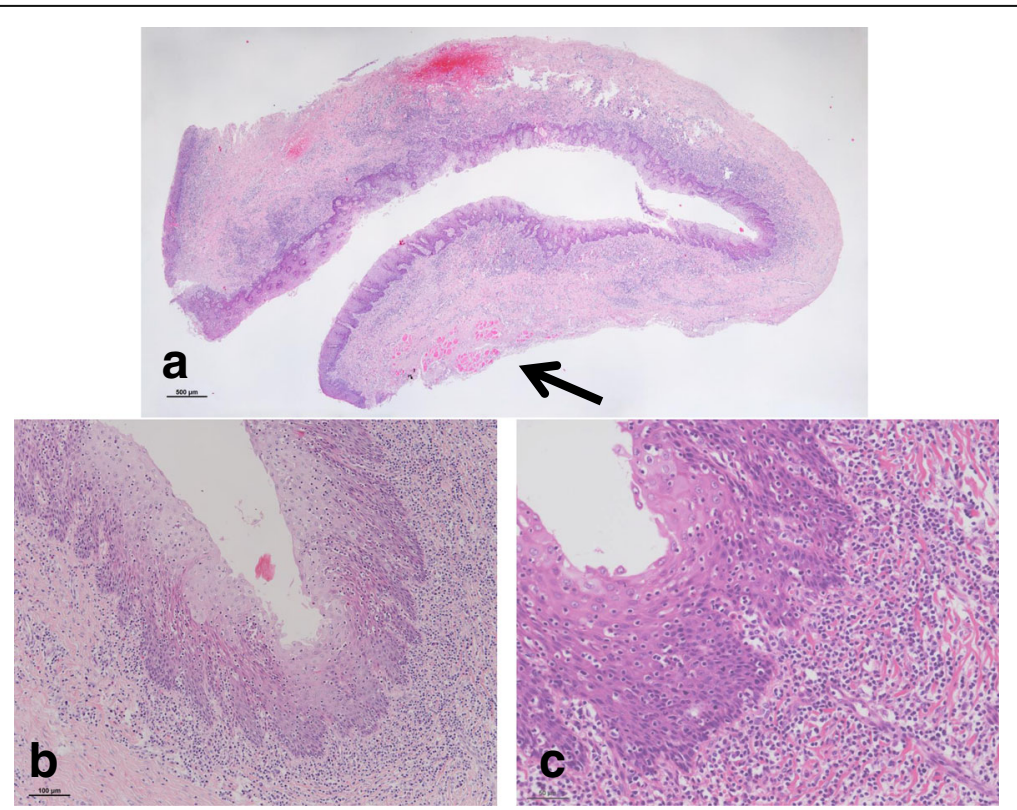

Fig. 6 Microscopic findings (with hematoxylin and eosin staining). Histopathological examination of the excised tissue specimen in a) loupe view reveals a pouched appearance with inflammatory infiltration in the stroma. The epithelial lining of the diverticulum is continuous with the surrounding buccal mucosa. The muscle tissue below the lesion is partially observed in the surrounding tissue (black arrow). b) Medium and high magnification ( $x$ 100 and $\times 200$ ) views of the excised specimen show normal buccal epithelium with a collagenous wall and inflammatory cell infiltration 
Table 1 Summary of the patient characteristics in 11 cases of diverticular lesions of the buccal mucosa

\begin{tabular}{|c|c|c|c|c|c|c|c|c|c|}
\hline Patient & Age (years)/Sex & $\begin{array}{l}\text { Chief } \\
\text { complaint }\end{array}$ & $\begin{array}{l}\text { Side of the } \\
\text { buccal mucosa }\end{array}$ & $\begin{array}{l}\text { Location within } \\
\text { the buccal mucosa }\end{array}$ & Diameter (mm) & Depth $(\mathrm{mm})$ & Treatment & Nation & Reference \\
\hline 1 & $86 / F$ & Swelling & Right & Inferior & 30 & 100 & Excision & $\begin{array}{l}\text { United } \\
\text { Kingdom }\end{array}$ & Bailey [2] \\
\hline 2 & $63 / M$ & Bad breath & Left & Posterior-inferior & 15 & 11 & Follow up & Japan & Takeda [3] \\
\hline 3 & $46 / M$ & $\begin{array}{l}\text { Food } \\
\text { impaction }\end{array}$ & Right & Inferior & 21 & 13 & Excision & Japan & $\begin{array}{l}\text { Yamamoto et } \\
\text { al. [4] }\end{array}$ \\
\hline \multirow[t]{2}{*}{4} & $89 / F$ & Symptomless & Right & Anterior & Not reported & $\begin{array}{l}\text { Not } \\
\text { reported }\end{array}$ & Follow up & $\begin{array}{l}\text { United } \\
\text { Kingdom }\end{array}$ & Rowson [5] \\
\hline & & & Right & Posterior & Not reported & $\begin{array}{l}\text { Not } \\
\text { reported }\end{array}$ & Follow up & & \\
\hline \multirow[t]{2}{*}{5} & $85 / M$ & $\begin{array}{l}\text { Food } \\
\text { impaction }\end{array}$ & Bilateral & Posterior-inferior & 7 & 7 & Excision & Japan & Kubo et al. [6] \\
\hline & & $\begin{array}{l}\text { Food } \\
\text { impaction }\end{array}$ & & Posterior-inferior & 3 & $\begin{array}{l}\text { Not } \\
\text { reported }\end{array}$ & Follow up & & \\
\hline \multirow[t]{2}{*}{6} & $80 / M$ & Symptomless & Bilateral & Posterior & 10 & 10 & Follow up & Taiwan & Yu [7] \\
\hline & & & & Posterior & 10 & 6 & Follow up & & \\
\hline 7 & $52 / \mathrm{M}$ & Symptomless & Right & Posterior-inferior & 3 & 7 & Excision & Japan & Terada et al. [8] \\
\hline 8 & $80 / M$ & Symptomless & Right & Inferior & 12 & 5 & Follow up & Japan & Terada et al. [8] \\
\hline 9 & $42 / M$ & Symptomless & Right & Inferior & 3 & 8 & Follow up & Japan & Terada et al. [8] \\
\hline \multirow[t]{2}{*}{10} & $60 / M$ & $\begin{array}{l}\text { Food } \\
\text { impaction }\end{array}$ & Right & Inferior & 5 & 10 & Excision & Japan & Ohnuki et al. [9] \\
\hline & & & Right & Inferior & 3 & 5 & Excision & & \\
\hline 11 & $66 / M$ & $\begin{array}{l}\text { Food } \\
\text { impaction }\end{array}$ & Left & Posterior & 13 & 8 & Excision & Japan & Present case \\
\hline
\end{tabular}

treatment should be recommended in symptomatic cases involving food impaction or voluminous diverticulum. Of the 11 reported cases, six cases underwent surgical excision and the remaining five cases received conservative treatment, including periodic irrigation and cleansing of the oral cavity. Since our patient complained of food impaction, local excision was the most appropriate treatment option. After the surgery, the patient's symptom of food impaction resolved and there has been no recurrence to date.

In conclusion, this report has described a rare occurrence of a diverticulum of the buccal mucosa. While a small number of other reports of this condition do exist, this is the first proven case, and we have provided substantial evidence in the form of clinical, pathological, and radiographic findings. In addition, we were able to elucidate that an idiopathic developmental anomaly caused by a buccinator muscle defect was responsible for the development of the diverticulum in this case.

\section{Abbreviations}

$\mathrm{CT}$ : computed tomography; MRI: magnetic resonance imaging

Acknowledgements

We wish to thank Editage for English language editing.
Availability of data and materials

All data generated or analysed during this study are included in this published report and its figures.

Authors' contributions

AM performed the clinical diagnosis and treatment, collected clinical data, and drafted the manuscript. TH conducted the pathological evaluation. SM $\mathrm{HN}$, and JK assisted in editing the pathology. KN and KT performed the literature search. $\mathrm{HH}$ suggested the treatment method. $\mathrm{KO}$ and $\mathrm{HD}$ assisted in editing the final version of the manuscript. All authors read and approved the final version of the manuscript prior to submission.

Ethics approval and consent to participate

Not applicable.

\section{Consent for publication}

Written informed consent was obtained from the patient for publication of this case report and any accompanying images. A copy of the consent is available for review by the Editor of this journal.

\section{Competing interests}

The authors declare that they have no competing interests.

\section{Publisher's Note}

Springer Nature remains neutral with regard to jurisdictional claims in published maps and institutional affiliations.

\section{Author details}

'Department of Oral Surgery, Sapporo Medical University School of Medicine, South-1, West-16, Chuo-ku, Sapporo 060-8543, Japan. ²Department of Surgical Pathology, Sapporo Medical University School of Medicine, South-1, West-16, Chuo-ku, Sapporo 060-8543, Japan. 
Received: 24 June 2017 Accepted: 31 May 2018

Published online: 07 June 2018

\section{References}

1. Gearhart SL, Bulkley G. Common diseases of the colon and anorectum and mesenteric vascular insufficiency. In: Kasper DL, Braunwald E, Fauci AS,

Hauser SL, Longo DL, Jameson JL, editors. Harrison's principles of Intern Medinternal medicine. 16th ed. New York: McGraw-Hill Medical Publishing Division; 2005. p. 1795-6.

2. Bailey BMW. A rare case of a diverticulum arising from the right buccal sulcus which extended into the neck-a case report. Br J Oral Surg. 1982;20:53-7.

3. Takeda Y. Diverticular pouch of the buccal mucosa: report of a case. Br J Oral Maxillofac Surg. 1992;30:128-9.

4. Yamamoto E, Kumagai S, Miyakawa A, Kyogoku J, Odajima T, Kohama G. Diverticulum-like lesion of buccal mucosa caused by partial defect of buccinator muscle-report of a case. J Jpn Stomatol Soc. 1989;38:508-12. Japanese

5. Rowson JE. Diverticulum of the buccal mucosa: report of a case. Br Dent J. 1993;174:175-6.

6. Kubo H, Nishida N, Hamamoto K, Niki H, Imoto K, Sakamoto T. Diverticular pouch of the buccal mucosa. Bull. of Kohka Public Hosp. 2003;99102(Japanese):6

7. Yu MZ. Abnormal bilateral diverticula of the buccal mucosa. Oral Surg Oral Med Oral Pathol. 1989;68:455-6.

8. Terada C, Asada K, Yamachika S, Tochihara S, Ishibashi K. Three cases of diverticulum of the buccal mucosa. J Jpn Oral Muco Membr. 2004;10:46-50. Japanese

9. Ohnuki H, lida A, Kobayashi T, Yamada E, Kiguchi T. A case of diverticulumlike lesion of the buccal mucosa. Jpn J Oral Maxillofac Surg. 2016;62:633-7. Japanese

10. Salmons S. Muscle. In: Williams PL, Bannister LH, Berry MM, Collins P, Dyson M, Dussek JE, et al., editors. Gray's anatomy: the anatomical basis of medicine and surgery. 38th. New York: Churchill Livingstone; 1995. p. 795-6.

\section{Ready to submit your research? Choose BMC and benefit from:}

- fast, convenient online submission

- thorough peer review by experienced researchers in your field

- rapid publication on acceptance

- support for research data, including large and complex data types

- gold Open Access which fosters wider collaboration and increased citations

- maximum visibility for your research: over $100 \mathrm{M}$ website views per year 